\title{
Review
}

\section{Nonviolence in political theory}

\author{
Iain Atack \\ Edinburgh University Press, Edinburgh, 2012, vi+202 pp., ISBN: 978-0748638710
}

Contemporary Political Theory (2016) 15, e32-e35. doi:10.1057/cpt.2015.15;

published online 10 March 2015

The twentieth century has seen the emergence of nonviolent action as a credible alternative in securing peaceful social and political change. Efforts to structure knowledge in this research area have been extensive, but Iain Atack's book, Nonviolence in Political Theory, indicates there is still sufficient room for further debate. The author explores central themes in classical political theory and the potential contribution of nonviolence theorists to the ongoing debates that surround them. The end result is a challenge to some of the prevailing discourses on the state and political power.

Atack begins his analysis with a focus on nonviolence theory and some of its concepts considered relevant to themes in political theory. The author defines nonviolence as 'collective action outside the formal institutions or procedures of the state that avoids systematic or deliberate use of violence or armed force to achieve its political or social objectives' (p. 8). Thus it is not only a matter of using nonviolent means but also of providing an alternative organizational blueprint through which popular power can manifest itself. In discussing how political and social changes are conceived within the boundaries of nonviolence theory, he draws on the well-known distinction between principled and pragmatic approaches to the use of nonviolence. The former is primarily driven by ethical considerations while the latter's choice of nonviolent methods is determined mainly by the perceived effectiveness in helping a movement reach its goals.

In tackling the issues put forward by social contract theorists, this distinction appears to fall into the background as Atack prefers to engage proponents of both sides together into the broader debates of social contract theory, where the author feels that nonviolence research can contribute the most to the field of political theory. The position of the state as a source of power and violence is evaluated. For political theorists, the peace is achievable through the limited use of legitimate violence exercised by the sovereign state. The author argues this conventional approach, whether in the more mainstream views of Hobbes, Locke and Rousseau, or the more radical conceptions of Sorel and Fanon, and does not foresee an end to the use of violence as a means of coercion and social transformation. The state has legitimacy,

() 2016 Macmillan Publishers Ltd. 1470-8914 Contemporary Political Theory Vol. 15, 1, e32-e35 
derived from the public, over the use of violence, but sometimes the state uses this right for illegitimate purposes. In that case, the public has the right to oppose the state, even by using violence.

Proponents of nonviolence challenge this approach. Even when it results in regime change, this type of opposition based on violent intervention does not fundamentally alter the violent character of the state order and precludes significant structural change. Their responses differ from Mohandas Gandhi's and Gene Sharp's mistrust of state intentions to Leo Tolstoy's outright rejection of the state as a type of organization. In discussing their positions in contrast to social contract theorists, Atack points at the attention of nonviolence thinkers to legitimizing social and political organization outside state structures as a counterweight to the existing order as well as to external threats. By studying closely the attitudes of these thinkers toward the conventional structures of the state, and considering their views on nonviolence as either principled or pragmatic, Atack comes up with the two types of nonviolent political action: civil resistance and transformative nonviolence.

Transformative nonviolence is closer to the aims of principled thinkers and focuses on changing the structure and moving beyond the conventional state and the exercise of violence as means of controlling the peace. Civil resistance is taken to signify a pragmatic approach, which works to make the state more representative while, in effect, protecting its existing form. Nonviolence, as civil resistance, avoids limitations on the state's legitimacy as sole possessor of the use of violence. Transformative nonviolence, in contrast, opposes all forms of concentration of power and violence in a centralized state, even if it is a democracy.

It is with the concept of power, specifically the idea of rejecting power concentration in a centralized structure, that nonviolence "marks one of the most distinctive contributions' (p. 100) to political theory. For social contract theorists, power is linked with human nature and the instinct of self-preservation. Power is actively sought and usually gained in competition at the expense of others. The state exists to exercise a monopoly over the power to coerce and punish for the benefit of the individuals. However, this type of power can easily be used for other purposes. Atack argues for a wider perspective on power, one that is built on the pluralistic view coming from nonviolence researchers like Kenneth Boulding and Gene Sharp. There are multiple sources of power, but it is the cooperation of individuals that confers the kind of legitimacy that the other forms of power depend on. Atack emphasizes a consent theory of power, attributable to Sharp, which is characteristic of nonviolence theory and becomes central in providing explanations of the effectiveness of nonviolent action. This approach opens up the possibility of a reevaluation of the relation between those who govern and those who are governed: there are multiple sources of power, located within society, which support the existing hierarchy. This makes nonviolent popular mobilization an effective action to bring changes in the structural organization of a society. 
Atack addresses the main criticisms directed against consent theory. First, a regime does not always depend on the approval of its people as its existing sources of power confer enough leverage for to maintain control. In such cases, Atack suggests, it is necessary to seek alternative modes of action that focus on eliminating the regime's sources of power, whether they are internal or external. Second, consent theory is accused of underestimating the relevance of hard power, understood as use of force, regarding the extent to which it shapes the field of action for nonviolent movements. The success of nonviolent action is dependent on the more conventional framework of power relations based in violence and the threat of violence. This type of pressure, whether it is from within the political system or from others states that are able to mobilize significant military capabilities, can affect the actions and fate of a nonviolent movement. To this criticism, Atack invokes the distinction, originating with Sharp, between two forms of hard power: coercion and violence. Coercion, 'as a mechanism for social change' (p. 139), is distinct from violence as it encompasses nonviolent action, including the withdrawal of consent. Lastly, critics argue that nonviolence theory largely ignores the systemic, 'structural limits' (p. 133) that work to reduce individual capacity to choose. Tolstoy and Gandhi emphasize that it is largely through behavioral change that individuals move toward 'non-cooperation with evil' (p. 140), identified in the regime and its values. However, Sharp acknowledges the role of social structures - meaning the distributions of power - above formal institutional arrangements, in mediating the relation between individual and government. It is up to the society to acknowledge these power structures and act to change them.

In the effort to develop a more comprehensive consent theory of power to explain nonviolent action more effectively, Atack invokes Gramsci's theory of hegemony and Foucault's perception of the ubiquity and pluralism of power. The Gramscian view adds to the perspective on consent as a prevalent form of control, which operates together with the coercive formal structure of the state, without replacing it. This approach also indicates civil society as having the potential to create and withdraw consent. Drawing from Foucault's perspective that power, rather than being concentrated in specific interactions, is characteristic to all relations, Atack indicates that there is no straightforward relation between those who govern and the rest of society. Rather, there are multiple channels of power that, Atack suggests, is indicative of 'multiple points of resistance' (p.154). Consent, or the lack of it, can thus manifest itself in a variety of ways.

Atack ends his general analysis by testing the ideas associated with nonviolence within the field of international relations. The elimination of war, which is a central concern of pacifism, becomes the main focus of attention. Nonviolence should not be equated with pacifism, although both are founded on a rejection of violence as a means to achieving a peaceful society. The author outlines three existing perspectives on the elimination of war: conscientious pacifism, anti-war pacificsm and anti-war internationalism. Conscientious (or absolute) pacifism and anti-war pacifism reject any participation in war, although they provide different reasons and solutions for it. 
'Conscientious pacifism is based on deontological objections to killing or the taking of a human life under any circumstances, whereas anti-war pacifism is derived from consequentialist considerations, associated with the destructiveness of modern technology or technological warfare' (p. 181). On the other hand, anti-war internationalism, although focused on the elimination of war as an ultimate goal, does not exclude the use of violent means. As neither conscientious nor anti-war pacifism offer viable alternatives to the use of coercion to enforce peace at the international level, Atack speculates about the role nonviolent theory could play in the reconciliation between pacifism and anti-war internationalism. The solution might reside, he suggests, in 'forms of active nonviolence' (p.178), as described in the works of Robert Burrowes on civilian and social defense, although this issue remains somewhat underdeveloped in Atack's study.

Atack's book expands on problems related to state-society relations, and more specifically on the problem of the state as a centralized authority with a monopoly over the use of violence. In this the reader can find one of the most interesting distinctions between the perspectives of social contract theory and nonviolence research. It is not only a matter of controlling the behavior of the state, but also of altering its behavior toward the use of nonviolence. The contribution of nonviolence research to political theory resides in a change of perspective, which may provide a better organization of the process of governance.

Alexandru Cristea

Kent State University, Kent, OH 44240, USA 